\title{
Anticonvulsant Activity of the Decoction of Crossopteryx febrifuga in Mice
}

\author{
DJ Bassoueka ${ }^{1}$, G. Taiwe Sotoing ${ }^{2}$, G F Nsonde Ntandou ${ }^{3}$, E. Ngo Bum ${ }^{4}$ \\ ${ }^{1,3}$ Laboratory of Biochemistry and Pharmacology, Faculty of Health, University Marien NGOUABI, BP: 69 Brazzaville Congo. \\ ${ }^{2,4}$ Department of Biological Sciences, Faculty of Science, University of Ngaoundere, PO Box 454 Ngaounderé, Cameroon
}

\begin{abstract}
The decoction of Crossopteryx febrifuga is evaluated for anticonvulsant activity in mice using strychnine (STR), picrotoxin (PIC), pentylenetetrazole (PTZ), maximal electroshock (MES) and isonicotinic hydrazid (INH) induced convulsions. A decoction of C. febrifuga at doses of 80 and $100 \mathrm{mg} / \mathrm{kg}$ protects $83.33 \%$ of mice against STR-induced convulsions. At the dose of $120 \mathrm{mg} / \mathrm{kg}$, it protects $100 \%$ of mice against PIC-induced convulsions. On PTZ-induced convulsions, C. febrifuga decoction protects $66.67 \%$ and $100 \%$ of mice, respectively at doses of 120 and $100 \mathrm{mg} / \mathrm{kg}$. While $66.67 \%$ and $83.33 \%$ of mice are protected against MES-induced convulsions respectively at the doses of 100 and $120 \mathrm{mg} / \mathrm{kg}$. Moreover, it increased the latency time of convulsions induced by INH at the doses of 80,100 and $120 \mathrm{mg} / \mathrm{kg}$.
\end{abstract}

Keywords: Epilepsy, anticonvulsant, Crossopteryx febrifuga, mice, decoction

\section{Introduction}

Belonging to Rubiaceae familly, C. febrifuga (Benth) is a species of origin Zambezian Sudano-GC-Z, it is a twisted tree with conspicuous tubular flowers, which is distributed throughouth the savanna region and forests of west and tropical Africa [1,3,4]. In Africa, C. febrifuga is used in traditional medicine to treat many diseases $[1,3]$. This plant is used by traditional healers to treat much affection. The roots juice diluted in water is used as bath against stomach pain; as nasal drop to calm headache, and as eye drops acting on the connective tissue of eye. All informants recognize that the contact of the juice with the mucosa is extremely painful. The decoction of the roots is also prescribed as a mouthwash to treat various oral diseases and tooth decay, in this last case, the treatment is followed by the application of the root powder on the decay tooth. Some fetishists use the plant to treat gonorrhea, epilepsy, heart aches and sores [3]. Many studies have been conducted on this plant; $C$. febrifuga has showed effect against peptic ulcer, acting by reducing the aggressive factor on the gastroduodenal mucosa or by increasing mucosal resistance against it [10]. C. fabrifuga decoction possess antiulcerogenic activity [22]. It is used traditionally for symptomatic relief of dry cough and for treatment of respiratory infections, fever, dysentery and pain [19]. It possesses potential hypoglycemic and hypolipidemic activies [19]. Infectious diseases, It is used to treat trypanosomias, staph aureus infections $[25,8]$. In northem Nigeria $C$. febrifuga is widely used in the therapeutic management of trypanosomiasis, malaria and painful inflammatory disorders [23]. This plant is also used in Congo-Brazzaville to treat headaches, migraine, bacterial infections and epilepsy [4]. Epilepsy is a disease that affects $0.5 \%$ to $1 \%$ of the population and whose cause is unknown in $80 \%$ of cases. The occurrence of epileptic discharge supposes coexistence of constitutional or acquired hyperexcitability and a hypersynchrony of a group of neurons. These basic electrophysiological disturbances result an imbalance in the neurotransmission system excitatory neurotransmitters which are amino acids (glutamate and aspartate) and inhibitor-mediated system by gammaaminobutyric acid (GABA) [1]. The etiologies for their part are discovered. They may be traumatic, tumor or infectious. Epilepsy is the most common disabling neurological condition. In Africa, its incidence is $73 \%$ inhabitants and a prevalence of 1 and $50 \%$. In Congo-Brazzaville, the prevalence of epilepsy is still unsolved. The literature reports no study on the anticonvulsant activity of this plant. The aim of the present study is to assess the anticonvulsant effect of $C$. febrifuga decoction in mice.

\section{Material and Methods}

\subsection{Plant Material}

Leaves of C. febrifuga was authenticated by $\mathrm{Pr}$. MOUTSAMBOTE, botanist at the National School of Agronomy and Forestry (SCSTA) of University Marien NGOUABI-CONGO. A voucher specimen (reference 8012) was deposited in the national herbarium of the Centre for Study of Plant Resources (CERVE) of CONGO-Brazzaville. These leaves were dried at room temperature $\left(25^{\circ}\right)$ in the laboratory for approximately 20 days. The decoction of the plant is prepared daily. $10 \mathrm{~g}$ of the plant powder was set in $50 \mathrm{ml}$ of boiling water for $20 \mathrm{~min}$ at $100^{\circ} \mathrm{C}$. After cooling, the decoction is filtered. The Filtrate volume measured for each test specimen was $10 \mathrm{ml}$. Another solution was prepared in the same manner and concentrated to oven. After concentration, the yield was $14.4 \%$.

\subsection{Biochemicals}

Diazepam, Clonazepam, Isonicotinic hydrazide acid (INH), Picrotoxin (PIC), Strychnine (STR) and Pentylenetetraol (PTZ) were used.

\subsection{Animals}

Male and female swiss mice (20-30g) were used in this research. Animals were obtained from laboratory of the Faculty of Science, University of Ngaoundere (Cameroon). 


\section{International Journal of Science and Research (IJSR) \\ ISSN (Online): 2319-7064 \\ Index Copernicus Value (2013): 6.14 | Impact Factor (2014): 5.611}

They were maintained under standard condition of light cycle (light/dark $12 / 12 \mathrm{~h}$ ), at the temperature of $25^{\circ} \mathrm{C}$, with free access to food and water.

\subsection{Strychnine-inducted convulsions test}

Six groups compound by six mice each one were formed and treated as follows: the negative control group received distilled water at a dose of $10 \mathrm{ml} / \mathrm{kg}$, the positive control group received clonazepam $3 \mathrm{mg} / \mathrm{kg}$ intraperitoneally, and the test groups are treated with decoction at doses 60, 80, 100 and $120 \mathrm{mg} / \mathrm{kg}$. Treatment was given $1 \mathrm{~h}$ prior to STR. Convulsions flowed by death were induced in mice by intraperitoneal injection of strychnine $2.5 \mathrm{mg} / \mathrm{kg}$. Then the mortality of animal was recorded. Animals that survived more than 10 min were qualified as protected $[11,15,16]$.

\subsection{Picrotoxin-inducted convulsions test}

Six groups compound by six mice each one were formed, and treated as follows, the negative control group received distilled water at a dose of $10 \mathrm{ml} / \mathrm{kg}$, the positive control group was treated with clonazepam $0.4 \mathrm{mg} / \mathrm{kg}$ intraperitoneally, the test group are treated with decoction of C. febrifuga at doses 60, 80, 100, and $120 \mathrm{mg} / \mathrm{kg}$. An hour later, the animals received picrotoxin by intraperitoneal injection of $7.5 \mathrm{mg} / \mathrm{kg}$. Mice were observed for $15 \mathrm{~min}$, the animals that survived more than 15 min were qualified as protected $[14,16]$.

\subsection{Pentylenetetrazol-inducted convulsions test}

Six groups compound by six mice each one were formed and treated as follows: The negative control group received distilled water $10 \mathrm{ml} / \mathrm{kg}$ p.o, the positive control group received clonazepam $0.1 \mathrm{mg} / \mathrm{kg}$ intraperitoneally. Convulsing crises were induced in mice by intraperitoneal injection of pentylenetetrazol $70 \mathrm{mg} / \mathrm{kg}$, the protected of the different treatments given $1 \mathrm{~h}$ before PTZ injection was valued. Animals that did not convulse within the $10 \mathrm{~min}$ were qualified as protect $[11,14,15]$.

\subsection{Maximal electroshock- induced seizures}

Mice were divided in Six groups compound by six mice each one, and Treated as follows, group 1 (negative control) received distilled water $10 \mathrm{ml} / \mathrm{kg}$ body weight, group II (positive control) was Treated with diazepam $50 \mathrm{mg} / \mathrm{kg}$ intraperitoneal, the four others groups (test groups) were treated with four different doses ( 60, 80, 100 and 120 $\mathrm{mg} / \mathrm{kg}$ ) of the plant decoction. Tonic convulsions of the hind extremities of mice were induced by passing alternating electrical current $(50 \mathrm{~Hz}, 20 \mathrm{~mA}, 0.2 \mathrm{~s})$ via two electrodes initially immersed in a solution of $9 \%$ of Nacl and them applied to mice eye $[14,17]$.The number of animals protected from tonic hindlinb extension was determined in each group.

\subsection{Isonicotinic hydrazide acide test}

Six groups compound by six mice each one were formed and treated as follows, the control group received the distilled water $10 \mathrm{ml} / \mathrm{kg}$, the reference group was treated with diazepam $10 \mathrm{mg} / \mathrm{kg}$ orally, the four test groups were orally treated with different doses of C. febrifuga decoction (60, 80, 100 and $120 \mathrm{mg} / \mathrm{kg})$. Then, animals were injected intraperitoneally with isonicotinic hydrazide acide (250 $\mathrm{mg} / \mathrm{kg}), 1 \mathrm{~h}$ after the different treatments, and latency times of clonic convulsants were recorded [14].

\subsection{Statistical Analysis}

Two parameters were measured: the latency time of seizures for INH test and the percentage of protection in mice against MES and chemically products induced convulsions. The averages of these parameters are compared with those obtained in mice of the negative control group. The results are expressed as mean \pm SEM. ANOVA followed by Dunnett test was used for Percentages of protection. The test " $t$ " student was used to analyze latency time of convulsions.

\section{Results}

\subsection{Percentage of mice protection against STR- induced seizures}

The decoction of C. febrifuga protected $50 \%$ of mice at doses of 60 and $120 \mathrm{mg} / \mathrm{kg}$, and $83.33 \%$ of mice (p $\leq 0.001$ ) at doses of 80 and $100 \mathrm{mg} / \mathrm{kg}$ against STR-induced seizures (Fig. 1)

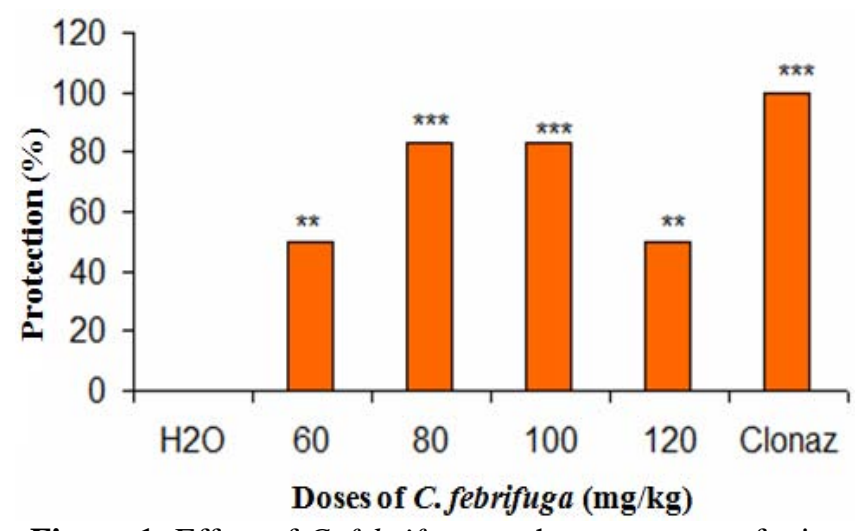

Figure 1: Effect of $C$. febrifuga on the percentage of mice protected against STR-induced seizures. Data are presented as mean \pm SEM. $\mathrm{n}=6$ per dose, $* * \mathrm{P} \leq 0.01$; *** $\mathrm{P} \leq 0.001$, significant difference from the negative control group. $\mathrm{H} 2 \mathrm{O}$ $=$ Distilled water (negative control), Clonaz $=$ Clonazepam 3 $\mathrm{mg} / \mathrm{kg}$ (positive control)

\subsection{Percentage of mice protection against PIC- induced seizures}

The decoction of C. febrifuga at doses 80, 100 and 120 $\mathrm{mg} / \mathrm{kg}$ protected receptively 50\% (p $\leq 0.01$ ), $83.33 \%$ and $100 \%(\mathrm{p} \leq 0.001)$ of mice against PIC-induced seizures (Fig. 2) 


\section{International Journal of Science and Research (IJSR) \\ ISSN (Online): 2319-7064}

Index Copernicus Value (2013): 6.14 | Impact Factor (2014): 5.611

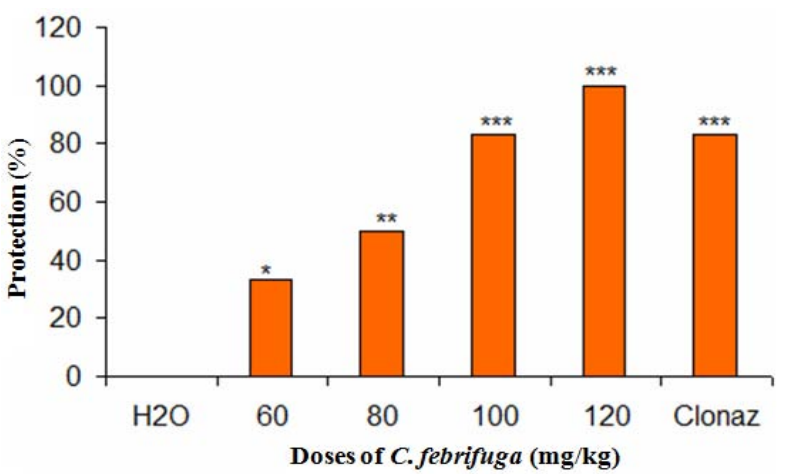

Figure 2: Effect of $C$. febrifuga on the percentage of mice protected against PIC-induced seizures. Data are presented as mean \pm SEM. $\mathrm{n}=6$ per dose, $* \mathrm{P} \leq 0.05 * * \mathrm{P} \leq 0.01$; *** $\mathrm{P} \leq 0.001$, significant difference from the negative control group. $\mathrm{H} 2 \mathrm{O}=$ Distilled water (negative control), Clonaz =

Clonazepam 0,4 mg/kg (positive control)

\subsection{Percentage of mice protection against PTZ- induced seizures}

At doses 80 and $120 \mathrm{mg} / \mathrm{kg}$, the decoction protected $66.67 \%$ (p <0.01) of mice, $100 \%$ of mice at the dose $100 \mathrm{mg} / \mathrm{kg}$ against PTZ-induced seizures (Fig. 3)

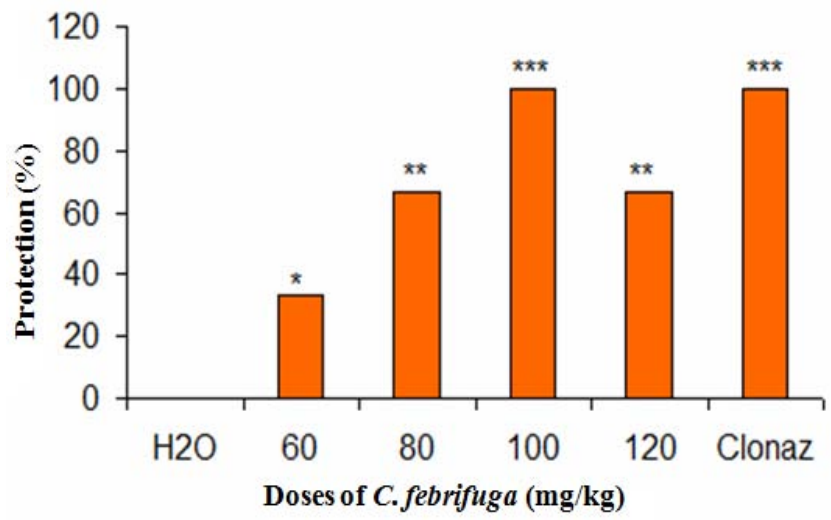

Figure 3: Effect of $C$. febrifuga on the percentage of mice protected against PTZ-induced seizures. Data are presented as mean \pm SEM. $\mathrm{n}=6$ per dose, $* \mathrm{P} \leq 0.05 * * \mathrm{P} \leq 0.01$; *** $\mathrm{P} \leq 0.001$, significant difference from the negative control group. $\mathrm{H} 2 \mathrm{O}=$ Distilled water (negative control), Clonaz =

Clonazepam 0,1 mg/kg (positive control)

\subsection{Percentage of mice protection against MES- induced seizures}

The fig 4 shows the percentage of mice protection against MES-induced seizures, it appears, at doses of 60, 80 and 120 $\mathrm{mg} / \mathrm{kg}$ the decoction protected receptively $66.67 \%$ of mice, and $83.33 \%$ of the mice $(\mathrm{p} \leq 0.001)$ at a dose of $100 \mathrm{mg} / \mathrm{kg}$.

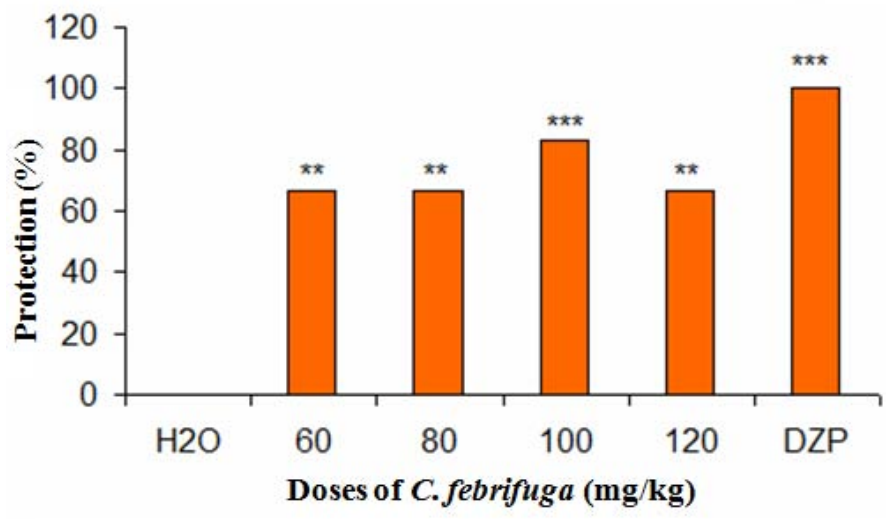

Figure 4: Effect of $C$. febrifuga on the percentage of mice protected against MES-induced seizures. Data are presented as mean \pm SEM. $\mathrm{n}=6$ per dose, $* \mathrm{P} \leq 0.05 * * \mathrm{P} \leq 0.01$; *** $\mathrm{P} \leq 0.001$, significant difference from the negative control group. $\mathrm{H} 2 \mathrm{O}=$ Distilled water (negative control), Diaz = DZP $50 \mathrm{mg} / \mathrm{kg}$ (positive control)

\subsection{Latency to onset of seizures by INH- induced seizures}

The decoction of $C$. febrifuga increased significantly the time to onset of seizures in the INH test $(p \leq 0.001)$ (Fig.5)

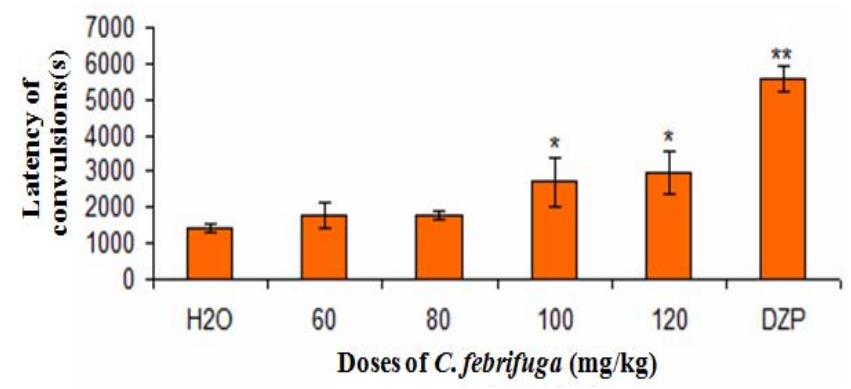

Figure 5: Effect of $C$. febrifuga on the convulsions induced in mice by INH, illustrated here are the time to onset of seizures against INH-induced convulsions. Data are presented as mean \pm SEM. $\mathrm{n}=6$ per dose, $* \mathrm{P} \leq 0.05 * * \mathrm{P} \leq$ 0.01 ; $* * * \mathrm{P} \leq 0.001$, significant difference from the negative control group. $\mathrm{H} 2 \mathrm{O}=$ Distilled water (negative control), $\mathrm{DZP}=$ Diazepam $10 \mathrm{mg} / \mathrm{kg}$ (positive control)

\subsection{Discussion}

C. febrifuga, Sudano-Zambezian species is widespread in all savanna and african tropical forests. The literature research conducted on this plant revealed that it has anti-convulsant potential $[1,4]$, which have not been subject to scientific studies. The anticonvulsant activity was studied with a decoction of C. febrifuga. Diazepam and clonazepam were used as reference molecules. Two parameters were evaluated, the latency time of convulsions and the percentage of protection of the mice. At doses 80 and 100 $\mathrm{mg} / \mathrm{kg}$, the decoction protected $83.33 \%$ ( $\mathrm{p} \leq 0.001$ ) against STR-induced convulsions. These results suggested that the C. febrifuga decoction has anticonvulsant activity and acts on glycine strynine-sensitive receptors [9]. On PIC- induced convulsions C. febrifuga decoction protected $83.33 \%$ of mice at a dose of $100 \mathrm{mg} / \mathrm{kg}$ and $100 \%$ of the mice at a dose of $120 \mathrm{mg} / \mathrm{kg}$. Antagonism of C. febrifuga against PTZinduced convulsion, at a dose $70 \mathrm{mg} / \mathrm{kg}$, can be explain by 


\section{International Journal of Science and Research (IJSR) \\ ISSN (Online): 2319-7064 \\ Index Copernicus Value (2013): 6.14 | Impact Factor (2014): 5.611}

the presence of compounds in the decoction that have anticonvulsant effect probably due to interaction with GABAergic neurotransmission [13, 18, 21]. It appears that at a dose of $120 \mathrm{mg} / \mathrm{kg}$ the decoction protected $66.67 \%$ of mice ( $<20.01$ ) and $100 \%$ of mice at a dose of $100 \mathrm{mg} / \mathrm{kg}$ very significantly. These results suggest that the decoction of $C$. febrifuga would be able to inhibit the PTZ effects. In addition, substances that block PTZ- induced convulsions would do by improving GABA neurotransmission receptors [18]. This extract may have fore there effects on GABAergic distribution. The decoction at doses 60,80 and $120 \mathrm{mg} / \mathrm{kg}$ protected $66.67 \%, 83.33 \%$ and $100 \%$ of mice against MESinduced convulsions respectivly. These results suggested that the decoction of $C$. febrifuga have anticonvulsant properties and act by inactivation of voltage-dependent sodium channels involved in the genesis of clonic convulsions $[7,18]$. Moreover, the decoction of C. febrifuga at all doses delayed the latency time of INH-induced convulsions. This suggested that $C$. febrifuga have anticonvulsant effect through interaction with GABAergic neurotransmission [2,5,6,7,12,23].

\section{Conclusion}

The results from our experimental study revealed that decoction of $C$. febrifuga administered per-os in mice, caused a protection of $50 \%$ of animals. At doses of 100 and $120 \mathrm{mg} / \mathrm{kg}$ the decoction of C. febrifuga protected $100 \%$ of animals against PTZ-induced convulsion and PIC-induced convulsion respectively as the reference molecule of diazepam. These results prooved that the plant possesses properties anticonvulsant and it can be continued to use by traditional healers for epilepsy treatment.

\section{Références}

[1] Adjanohoum EJA, and al. (1968) Contribution aux études ethnobotaniques et floristiques en République du Congo. Acct. Paris. 150

[2] Ahmadiani A., Mandgary A., Sayyah M.,(2003) Anticonvulsivant effect of flutamide on seizures induiced by pentylene tetrazole, involvement of benzodiazepine receptors, Epilepsia, 44, 629 - 625.p

[3] Boukef M.K. (1986) Médecine traditionnelle et pharmacopée .Editions ACCT, Francophonie .360.p

[4] Bouquet A (1972) Féticheurs et Médecines traditionnelles du Congo (Brazzaville). Travaux et documents de l'ORSTOM, paris. 36, 282p

[5] De Deyne P.P., D’hooge R., Maresceau B., Pei Y. (1992) Chemical model of epilepsy research. 12: 87-110

[6] Doctor S.V., Costa L.G., Murphy S.D., (1982). Effect of trimethyltin on chemically-induced seizures. Toxicology Letters. 13: 217 - 223 p.

[7] Holmes G.L. (2007). Animal model studies: application to human patients, Neurology, 69: 28 - 32

[8] Hostehmann K., Marston A., Ndjoko K. and Wolffender J., (2000) The potential of African plants as source of drugs: curr organic chem. 4: 973-1010.

[9] Goth A., (1984) Medical Pharmacology, 11th Edition Mosby, St Louis, USA. 815.

[10] Larach J.R., Malage J.R., (1982) Physiological basis for drug treatment in peptic ulcer; an overvieuw. in: Pfeiffer CJ. Editor. Drugs and peptic ulcer diseas therapeutic agents for peptic ulcer diseas. I. Boca Raton, FL: CRC Press.

[11] Lehmann J, Hutchison A, MC Pherson SE, Mondadou C.; Schmutz M, Sinton C, Murphy DE, Steel FJ, Williams M, Cheney DL, Wood PL. CGS 19755. (1988) a Selective and competitive N-methyl- aspartate; type excitatory amino acid receptor antagonist. Journal of pharmacology 246: 65-75

[12] Löscher W., Schmidt D., (1988). Which animal model should be used in the search for new antiepileptic drugs. A proposal based on the experimental and chemical consideration. Epilepsy Research, 2: 145 - 181.

[13] Mustafa AMS., Ali AM., A. ( 2008) substance in broad beans (vicia faba) is protective against experimentally induced convulsions in mice. Epilepsy Behav. 12: 25-9.

[14] Ngo Bum E., Schmutz M., Meyer C., Rakotonirina A., Rakotonirina S.V., Bopelet M.

[15] Porte C., Jeker A., Olpe H.R., Herrling P, (2001). Anticonvulsivant properties of the methanolic extract of Cyperus articulatus (Cyperaceae), Journal of ethnopharmacology, 76:145 - 50

[16] Ngo Bum E, Dawack DL, Schmutz M, Rakotonirina A, Rakotonirina SV, Portet C, Jeker A., Olpe HR., Herrling P. (2004) Anticonvulsivant activity of Mimosa pudica decoction. Fitoterapia. 75: 310-5

[17] Ngo Bum E, Naami YFC, Soudi S, Rakotonirina SV, Rakotonirina A. (2005) Psorospermum febrifugum spach (hpericaceae) decoction antagonized chemicallyindused convulsions in mice. Int J Pharmacol. 1: 11821.

[18] Ngo Bum E. Ngoupaya G.T, Talla E, et al. 2008 The anticovulsant and sedative propeties of ítems of Cissus quadrangularis in mice. Aft J Pharm Pharmacol. 2: 427

[19] Ngo Bum E., Taiwe G.S., Nkaissa L.A., Moto F.C.O., Seke Etet P.F., Hiana I.R., T., Rouyatou, Papa Seyni, Rakotonirina A., Rakotonirina S.V. (2009a).Validation of anticonvulsant and sedative activity of six medicinal plants. Epilepsy and Behavior, 14: $454-458$

[20] Ojewale A.O., Olaniyan O.T., Yemitan O.K., Odukanmi O.A., Dare B.J., Nnaemeka W.S., Omoaghe O., Akiengebade A.M., Ogunmodede O.S., Adebari A.O. (2013) Hypoglycemic and hypolipidemic activities of ethanolic roots extracts of Crossopteryx fébrifuga in Alloxani-induced Diabetic rats. Mintage journal of pharmaceutical and medical Sciences 2: 4.

[21] Oudugbemi T. (2006) Medical plant by especies names: Outlines and Pictures of medicinal plants from Nigeria, Lagos, University press. 596.

[22] Peréz-saad H., Bbuznego MT. (2008) Behavioral and antiepileptic effets of acute administration of the extract of the plant Cestumnoctumum LIN ( lady of the night). Epilepsy Behav. 12: 366-72.

[23] Salawu Oluwakanynsola Adeola., Tyani Adeniyi Yahaya., Babayi Hafsatu., Nwaeze Angela Chinwe., Ezlonu Chidimma Mary Jane., Igwe Sunday and Ndukuba Mary Adonna (2011) Gastro-protective effect of Crossopteryx febrifuga in wistar rats. Afr J Tradit complement Altem Med. 8(3): 300-3006

[24] Salawu O.A., Chindo B.A., Tyani A.Y. and Adzu B. (2008) Analgesic, ant-inflammatory, anty-pyretic and antiplasmodial effects of the methanilic extract of 


\section{International Journal of Science and Research (IJSR) \\ ISSN (Online): 2319-7064}

Index Copernicus Value (2013): 6.14 | Impact Factor (2014): 5.611

Crossopteryx fébrifuga. J. Med plant Res. 2(8): 213218.

[25] Schmidt TJ., Hildebrand MR.,Willuhn G. (2003) New dihydrobenzofurans and triterpenoids from roots of Microglossa pyrifolia. Planta Med. 69: 258-64.

[26] Yusuf A.B., Hiyasu B., Abubakar A., OneyKewelu E.L. and Bot D.Y. (2004) Preleminary evaluation for antitrypanosomial activity of aquous stem bark extract of Crossopteryx fébrifuga in T. Congolensis infection in rat. Presented at the 31st West African society of Pharmacology conference, Kano, Nigeria. 